been conferred this year on Dr. R. C. Sutcliffe, a deputy chief scientific officer in the Meteorological Office, for his outstanding work in the field of synoptic and dynamical meteorology. The award was made at the annual general meeting of the Society on April 20. The citation stated: “Dr. Sutcliffe's success as a practical weather analyst and forecaster is matched by his achievements as a practical theorist and teacher. To his fundamental researches we owe a great deal of our knowledge of the effect of temperature patterns on development. His two-layer model of atmospheric motion has become the basis of a practical method of numerical weather forecasting. To his ability and enthusiasm is due in large messure the remarkable success of the Napier Shaw Laboratory. His engaging popular style combined with his seriousness of purpose have made him one of the most successful teachers and there can be few meteorologists whose understanding has not been deepened and broadened as a result of his efforts".

\section{Canadian Award in Meteorology: \\ Dr. John Patterson, O.B.E.}

IN 1947, shortly after Dr. John Patterson's retirement from the post of controller of the Canadian Meteorological Service, a fund was established by donations from his many friends and associates, from which a Patterson Medal is to be awarded annually to a Canadian resident for distinguished service to meteorology. The fund is held in trust by a group of the senior officials in the Canadian Meteorological Service, who will annually appoint an award committee composed of representatives from the Meteorological Service, research institutions, Canadian universities and Canadian industry. The first award of the Medal has recently been made to Dr. Patterson himself. Dr. Patterson, who is eighty-three, was controller of the Canadian Meteorological Service during 1929-46. He graduated from the University of Toronto in 1900, with the gold medal in physics, and was then awarded an 1851 Exhibition Science Research Scholarship which took him to England for two years at the University of Cambridge. He later became professor of physics in the University of Allahabad for two years, after which he was appointed head of the Indian Weather Service. He joined the Canadian Weather Service in 1910. During his association with the Service, Dr. Patterson contributed to the design of a series of instruments especially suited to rugged Canadian weather conditions, and under his guidance the Service expanded rapidly, in keeping with the heavy demands placed upon it by the British Commonwealth Air Training Plan of the Second World War. $\mathrm{H}_{\Theta}$ is known internationally for his personal interest and leadership in the World Meteorological Organization and other scientific societies.

\section{Upper Atmosphere Research by the National Research Council of Canada}

Dr. Peter M. Mruman, formerly chief of the Stellar Physics Division of the Dominion Observatory, Canada. has joined the National Research Council of Canada and will work in the Division of Radio and Electrical Engineering, leading the section on upper atmosphere research. 'Dr. Millman, who was born in Toronto in 1906, graduated from the University of Toronto in 1929, and then took a Ph.D. in astronomy at Harvard University in 1932. During 1933-45 he was on the staff of the David Dunlap Observatory and lecturer in astronomy, University of Toronto, and since then he has worked at the Dominion Observatory, being chief of the Stellar Physics Division since 1951. During 1941-46 he was in the Royal Canadian Air Force, first as a navigation instructor and later in charge of operational research, retiring with the rank of squadron leader.' Dr. Millman's investigations for the past twenty years have been concerned mainly with meteors and meteorites; but he has also worked in the field of stellar radial velocities and in the observation of solar eclipses from the air.

\section{Martin Barry (1802-55)}

MaRtin BariRY, who died one hundred years ago on April 27, 1855, is an interesting example of an amateur who made valuable contributions to science. Born at Fratton, in Hampshire, on March 28, 1802, he studied medicine in Paris, Erlangen, Berlin, Edinburgh and London, and graduated M.D. of the University of Edinburgh in 1833. In the following year, while on a visit to Switzerland, he climbed Mont Blanc in mid-September-later in the season than any successful attempt previously recorded-and published a paper "On Dyspncea and other Sensations experienced on the Summit of Mont Blanc" in the Proceedings of the Royal Society of Edinburgh. For a year he studied embryology under Friedrich Tiedemann at Heidelberg, and his "Researches in Embryology" (1838-40) won him one of the Royal Medals of the Royal Society in 1839 ; he was elected a Fellow in 1840. Barry is principally known for two fundamental discoveries: the segmentation of the yolk in the mammiferous ovum obtained from the Fallopian tube, and the penetration of spermatozoa within the zona pellucida of the rabbit's ovum. While the ovum and spermatozoon had each been known for many years, their union in the process of fertilization had so far remained conjectural. Barry observed an orifice in the zona pellucida, its form "suggesting the ides of the membrane having become cleft", and described within it some five hours after coitus, "an object very much resembling a spermatozoon". His findings, doubted at first, were afterwards confirmed by T. L. W. Bischoff and others. Barry was one of the first in 1840 to note proliferation of cells by division of the nucleus and cytoplasm. In 1844 he became house-surgeon to the newly founded Royal Maternity Hospital in Edinburgh; but, his health failing, he returned to the Continent of Europe, where he cultivated his intimate friendship with Johannes Müller, Theodor Schwann, Rudolph Wagner, J. E. Purkinje and G. G. Valentin. In 1853 he settled at Beccles in Suffolk, his sight almost ruined by the strain of microscopic work, and a victim of neuralgia and insomnia. He died at the early age of fifty-three.

\section{Poliomyelitis Vaccine Tests in Great Britain}

THe Medical Research Council has announced that a limited amount of anti-poliomyelitis vaccine, similar to that used in the United States, will be available to the Council this year and that small groups of children will be vaccinated in a few centres in Great Britain and Northern Ireland, where there are laboratories engaged in studying the poliomyelitis virus. By means of blood tests on the vaccinated children, information on the response to the vacine will be obtained, and this will be compared with the information obtained from laboratory tests. The results will be used for planning the most effective use of the larger quantities of vaccine which 